\title{
Environmental Impacts of Waste Disposal: An Overview on the Disposal of Polyethylene Bags in Gusau City Zamfara State.
}

\author{
*Usman Lawan Muhammad ${ }^{1}$, Ibrahim Muhammad Shamsuddin,3, Aliyu Abubakar \\ $\mathrm{Shehu}^{4}$, Kurfi Muhammad Yahaya ${ }^{4}$, Ma'aruf $\mathrm{Nuhu}^{5}$ \\ 1 *Department of Chemistry, Al-Qalam University, Katsina Nigeria. \\ ${ }^{2}$ Department of Chemistry, Sa'adatu Rimi Collage of Education Kumbotso, Kano Nigeria \\ ${ }^{3}$ Break-Free Plastic Movement, Nigeria. \\ ${ }^{4}$ Save the Nature Foundation \\ ${ }^{5}$ Department of Pure and Industrial Chemistry, Bayero University Kano \\ Uslamad50@gmail.com (U.L.Muhammad)
}

\begin{abstract}
The environmental impacts of waste disposal of polyethylene bags and seasonal variation of polyethylene disposal in Gusau City of Zamfara state, Nigeria was investigated. General public waste disposals from homes, schools and daily markets, were randomly selected for data collection. The data showed that polyethylene waste is generated more in the dry season than the wet season. The result also showed that table water sachet has 75\% disposal. This is because, sachet water is cheap and consumed throughout the year with very little seasonal variation while at homes and markets also, displayed a very interesting pattern. The study revealed that in the market, polyethylene for table water sachets (10\%) was the least, followed by ice cream sachets (6\%), assorted items (5\%) and biscuits wrappers (4\%). On the other hand, the results showed that, at home, polyethylene for assorted items was the highest (61\%), closely followed by biscuit wrappers (20\%), table water sachets (14\%) and ice cream wrappers $(5 \%)$ respectively. Polyethylene waste poses various threats to public health and adversely affects flora and fauna as well as the environment especially when it is not appropriately collected and properly disposed. And based on this research, it was found that most of the public do not know the advantages, disadvantages and the health effects of rampant and improper disposal of polyethylene bags. It is concluded that aggressive campaign and enlightenment of the masses on the threats posed by polyethylene bags pollution should be carried out to prevent further negative environmental impact.
\end{abstract}

Keywords: polyethylene; pollution; environmental; impact; campaign; enlightenment

\section{Introduction}

Human activities generate many by-products which are generally seen as useless and discarded as wastes (Palmer, 1998). These massive amounts of wastes subsequently find their ways into the ground, air and water every year (Day, 1998). Increasing population growth accompanied by rapid urbanization and industrialization has resulted in dramatic increases in the volume of wastes generated by modern societies. Increase in economic activities and food consumption by humans and changing lifestyles generate a massive volume of domestic wastes which creates a critical problem in the developed and developing countries of the world (Palmer, 1998). Solid waste management has emerged as a major environmental threat for cities in developing countries worldwide. In a survey released by UNDP in 1997, 151 mayors from around the world ranked solid waste disposal problem as their second most urgent urban challenges surpassed only by unemployment and followed by urban poverty (Agagu, 2008). Considerable percentage of urban waste in developing countries is deposited either on the roads, or road sides, unapproved dump sites, in water ways drainage system, or in open sites which adversely affect environmental friendliness. In fact, solid waste poses various threats to public health and adversely affects flora and fauna as well as the environment especially when 
it is not appropriately collected and disposed (Geraldu, 1995). Besides the above mentioned effects of solid wastes, they result in emission of toxic chemical to the atmosphere and to the soil whenever they are degraded or burnt. The trees absorb these toxins through their root system which retards growth rates and consistently results to death (Addison et al 1991).

Polyethylene (bags) gained an increasing popularity amongst consumers and retailers. They are available in huge numbers and varieties across the world. It is estimated that around 500 billion plastic bags are used every year worldwide (Geographical 2005 Spokes KA, 2007 and). This wide spread utilization is attributed to their cheapness and convenience to use. The vast majority of these bags are discarded as wastes usually after a single use. It is also believed that after their entry into environment, polyethylene (bags) can persist up to 1000 years to degrade and hence pose a disposal challenge without being decomposed by sun light and/or microorganisms (Steven E. 2001 and UNEP 2005a). Accumulation of some polyethylene bags wastes causes environmental pollution that can be manifested in number of ways. One of the problems is deterioration of natural beauty of an environment (Anthony A. 2003). Another common problem associated with these wastes is death of domestic and animals. This necessitates for proactive measures in order to safeguard animal species against extinction (flores MC. 2008 and Macur BM. et al; 2009].

Blockage of sewerage systems is becoming a common problem in cities and instruments such as levies and taxes to restrict the use and production of polyethylene bags (Hasson et al, 2007 and Xing X. 2009). Though, they are not as such effective, voluntary initiatives have also been attempted in some countries to reduce polyethylene bags use problems in environment.

Different reports (Bjerkli CL, 2005) Showed that plastic bags are still causing severe environmental pollutions and also human and animal health damages in urban and rural areas of the country. Some of the basic reasons could be poor waste management and perhaps lack of awareness about the negative impacts of plastic bags (Ramswamy V. et al, 2011).

The use of polyethylene bags increased dramatically and can be found everywhere. They are so light that wind can take them everywhere. They are too cheap to be collected, reused or recycled.

This paper investigates the environmental impacts of polyethylene bags in Gusau City seasonal variation in the generation and disposal the risk on highest disposed of both at homes and markets and, also examines the overview of public based on advantages and disadvantages and the risks posed by polyethylene to human health and environment.

Nylon or polyethylene bags are non-biodegradable but its strength while in water or soil deteriorates with time. During the deterioration period, the chemicals with which, the polyethylene (bags) composed are gradually released and thus polluting the soil or water for upward of 40 years. With this in mind, and going by the volume of disposal of polyethylene dumped into our water bodies, and land, one became worried with the magnitude of environmental pollution in Nigeria in the coming years. One is not particularly certain, when exactly, the use of polyethylene bags started in this country but, what cannot be disputed is that its usage and the concomitant environmental pollution has been on steady rise since the 1970s when rapid urbanization, bludgeoning socialization, serious cultural integration and technological development resulted in a shift in the average Nigeria life style. This shift in life style from the traditional to the Western ways of living and feeding, together with the placement of aesthetics over and above the use of natural leaves as wrappers, accounted for some of the basic reasons for the continued. 


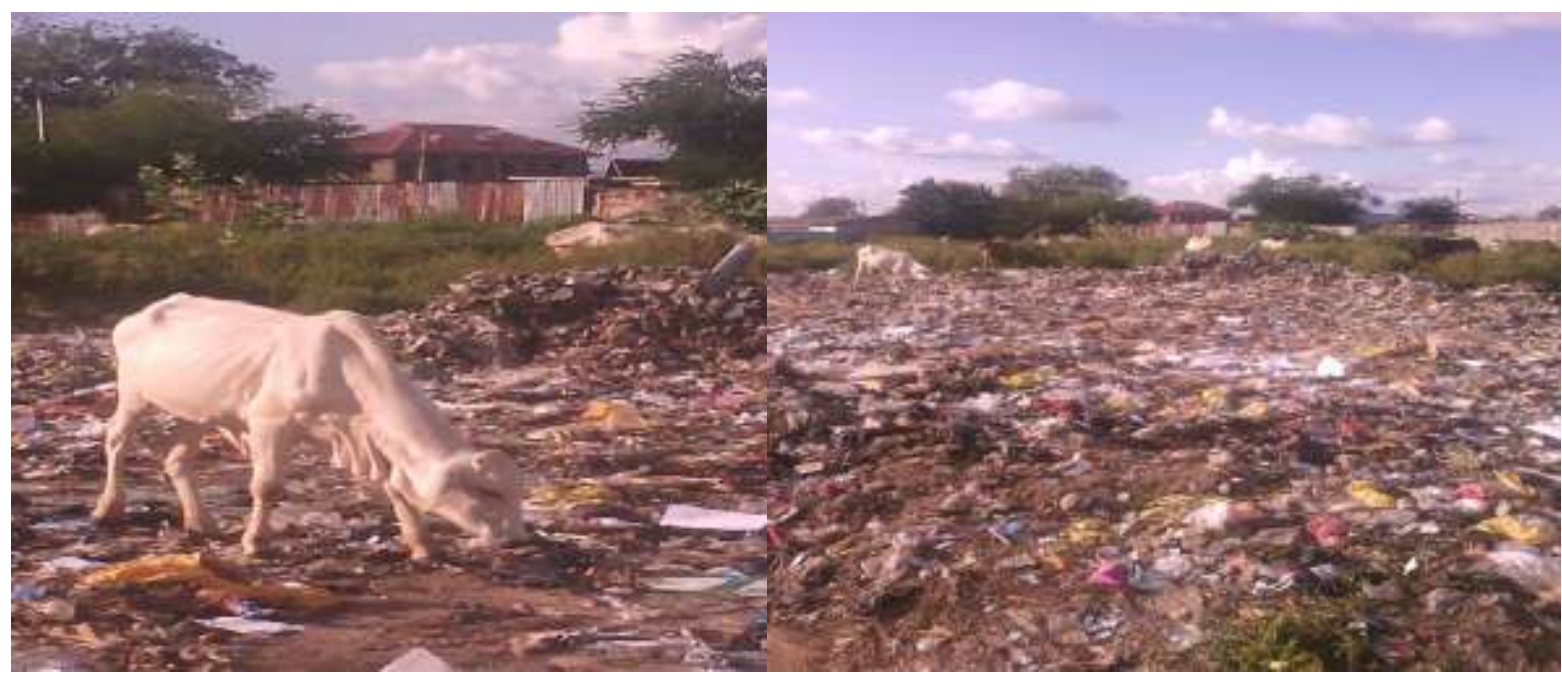

Figure I. Picture of some place with rampant disposal of polyethylene bags in Gusau city of Zamfara state Nigeria

\section{Study Area}

\section{Materials and Methods}

Gusau is a city and local 1 government area located in North West, of Nigeria. It is the capital of Zamfara State. The LGA has an area of $3,364 \mathrm{~km}^{2}$ and populations of 383,162 according to 2006 census.

It is located on the Sokoto River in the savanna region of Nigeria. The river provides access to water supplies during the dry season. It serves as a major industrial center of northern Nigeria. Industries in the city include textile manufacturing, groundnut and tobacco processing, and cotton ginning. The city is active in mining the deposits of gold and diamonds in the surrounding countryside. Gusau is connected by roads and a railroad to other cities in the region; the city also has a regional airport. The city is part of the Hausa- Fulani cultural region of northern Nigeria. It has a substantial Muslim population and contains numerous mosques and Muslim organizations. Archaeological evidence suggests that Gusau was occupied by Old Stone Age (37,000-15,000 years ago) peoples and many quartz tools from this period have been found in the area. (Microsoft $₫$ Encarta $® ~ 2009)$. (Encyclopædia Britannica 2009).

The study employed the use of questionnaire to acquire data relating to environmental impacts of polyethylene bags in Gusau city. Three hundred and fifty (350) copies of questionnaire were administered to the public by using random sampling technique which gives room for equal chance of any community member to be chosen in the study area but only three hundred (300) questionnaire were retrieved and all further statistical analyses were based on the retrieved questionnaire. Descriptive statistics was used to explain the frequencies of the variables in terms of their percentage. Results of the analysis were presented using tables and graphs such as pie chart, bar chart among others.

\section{Result and Discussion}

Table 1 shows the age rate of respondents in the study area. The statistics indicated that male were $55 \%$ while female were $45 \%$ suggesting that males were more than females in the study area. The result of the analysis also shows that most of the respondents fall within the 
age of 0-18 years, 19-35years, 36-50 years and 51 -above which are 28\%, 50\%, $16.4 \%$ and $5.6 \%$ respectively of total respondents. Furthermore, it is also revealed that most of the respondents had attained a reasonable level in education with about $45.7 \%$ as university students, $30.3 \%$ are N.E.C students, $5 \%$ graduates while $15 \%$ accounted for those with secondary education respectively.

Table I: presents the season which has highest disposal polyethylene bags in the study area. Of the total respondents, $70 \%$ affirmed that highest disposal is being experienced during raining season in the area while $24.8 \%$, believed that the area experienced much disposal during dry season and $5.2 \%$ the area experienced highest during the both season respectively.

Table 1. Presents the sex, ages, education levels of the respondents and season which has highest disposal polyethylene bags in the study area.

\begin{tabular}{|c|c|c|c|c|c|}
\hline \multicolumn{3}{|c|}{ sex of respondents } & \multicolumn{3}{|c|}{ level of education of the respondents } \\
\hline $\operatorname{sex}$ & Frequency & Percent & Levels & $\begin{array}{l}\text { frequenc } \\
y\end{array}$ & percent \\
\hline Male & 165 & $55 \%$ & Secondary & 45 & $15 \%$ \\
\hline Female & 135 & $45 \%$ & tertiary education & 137 & $\begin{array}{l}45.70 \\
\%\end{array}$ \\
\hline \multirow[t]{2}{*}{ Total } & 300 & $100 \%$ & N.E.C students & 103 & $\begin{array}{l}34.30 \\
\%\end{array}$ \\
\hline & & & Graduate & 15 & $5 \%$ \\
\hline \multicolumn{3}{|c|}{ ages of respondents } & Total & 300 & $100 \%$ \\
\hline Ages & Frequency & Percent & \multicolumn{3}{|c|}{$\begin{array}{l}\text { seasons for the highest disposal } \\
\text { polyethylene }\end{array}$} \\
\hline $0-18$ & 84 & $28 \%$ & Seasons & $\begin{array}{l}\text { frequenc } \\
y\end{array}$ & $\begin{array}{l}\text { Percen } \\
t\end{array}$ \\
\hline $19-35$ & 150 & $50 \%$ & raining season & 210 & $70 \%$ \\
\hline $36-50$ & 49 & $16.40 \%$ & dry season & 74 & $\begin{array}{l}24.60 \\
\%\end{array}$ \\
\hline 51-above & 17 & $5.60 \%$ & both season & 16 & $5.40 \%$ \\
\hline Total & 300 & $100.00 \%$ & Total & 300 & $100 \%$ \\
\hline
\end{tabular}

Table 2 shows, The result of the analysis on the rate of occurrence or causes of pollution by polyethylene bags in the study area vividly revealed that $65 \%$ of total respondents agreed that polyethylene bags is the major causes of pollution, while $25 \%$ agreed that are agricultural west are major causes of pollution and $10 \%$ agreed that it causes by other things.

Based on the respondents on the places with highest disposal and the types polyethylene bags disposed in the area show that: Table water sachet topped the highest with $75 \%$ because; it is consumed throughout the year with very little seasonal variation while it's also revealed that in the market, polyethylene for table water sachets $(10 \%)$ was the least, followed by ice cream sachets $(6 \%)$, assorted items $(5 \%)$ and biscuits wrappers $(4 \%)$. On the other hand based 
on the respondents, the results showed that, at home, polyethylene for assorted items was the highest (61\%), closely followed by biscuit wrappers (20\%), table water sachets (14\%) and ice cream wrappers $(5 \%)$ respectively. for assorted items ranked lowest in the market because they are used in wrapping items in the market but disposed of at home having removed the contained items for cooking or storage. The generation of table water sachets was lowest at home but highest in the market. This is so because most homes have refrigerator where they can store water for it to get cool/cold. This finding is in agreement with Aziegbe's (2007) study in Benin, Edo State, Nigeria.

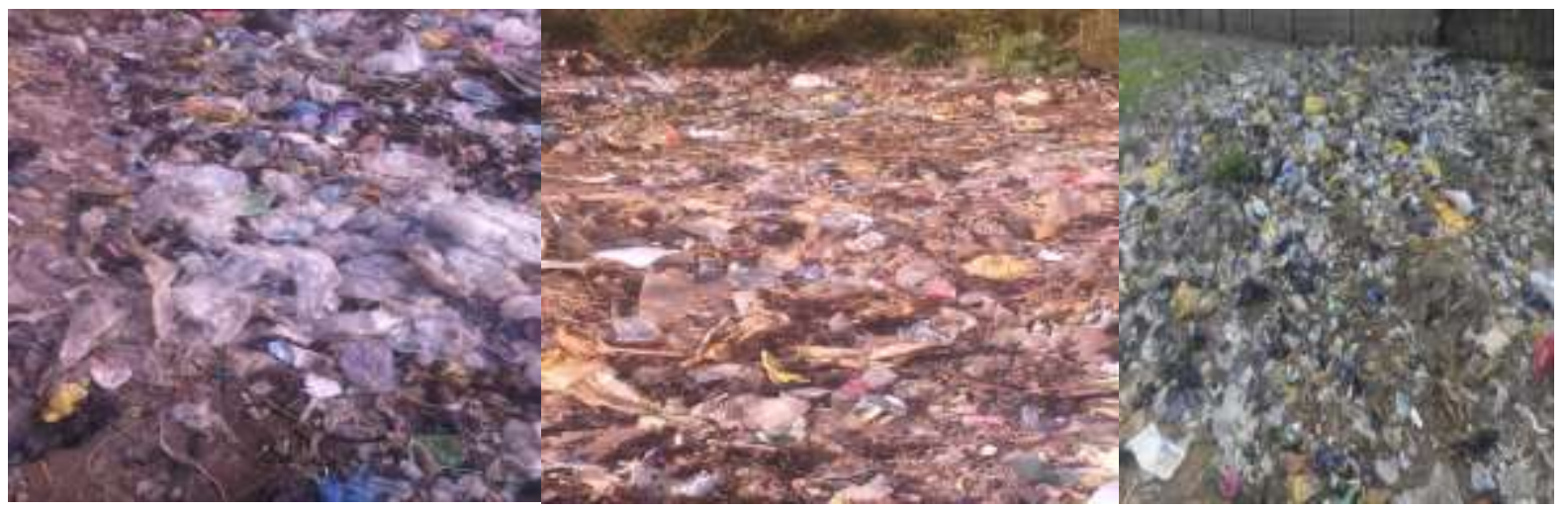

Figure 2. Pictures of some communities and markets in Gusau city Zamfara state

Table 2. The result of the analysis on the types and the places with highest disposal of polyethylene bags in the study area

\section{Places with the highest disposal of polyethylene bags based on the responses}

\begin{tabular}{|c|c|c|c|c|c|}
\hline $\begin{array}{l}\text { polyethylene } \\
\text { bags }\end{array}$ & Percent & requency & polyethylene bags & Percent & Frequency \\
\hline $\begin{array}{l}\text { sachet water } \\
\text { at home }\end{array}$ & $75 \%$ & 225 & $\begin{array}{l}\text { assorted items at } \\
\text { home }\end{array}$ & $61 \%$ & 183 \\
\hline $\begin{array}{l}\text { sachet water } \\
\text { at market }\end{array}$ & $10 \%$ & 30 & $\begin{array}{l}\text { biscuit wrappers } \\
\text { home }\end{array}$ & $20 \%$ & 60 \\
\hline $\begin{array}{l}\text { ice cream } \\
\text { home }\end{array}$ & $6 \%$ & 18 & $\begin{array}{l}\text { sachet table waters } \\
\text { market }\end{array}$ & $14 \%$ & 42 \\
\hline $\begin{array}{l}\text { assorted } \\
\text { items } \\
\text { markets }\end{array}$ & $5 \%$ & 15 & ice cream market & $5 \%$ & 15 \\
\hline $\begin{array}{l}\text { biscuit } \\
\text { wrappers } \\
\text { markets }\end{array}$ & $4 \%$ & 12 & Total & $100 \%$ & 300 \\
\hline Total & $100 \%$ & 300 & & & \\
\hline
\end{tabular}




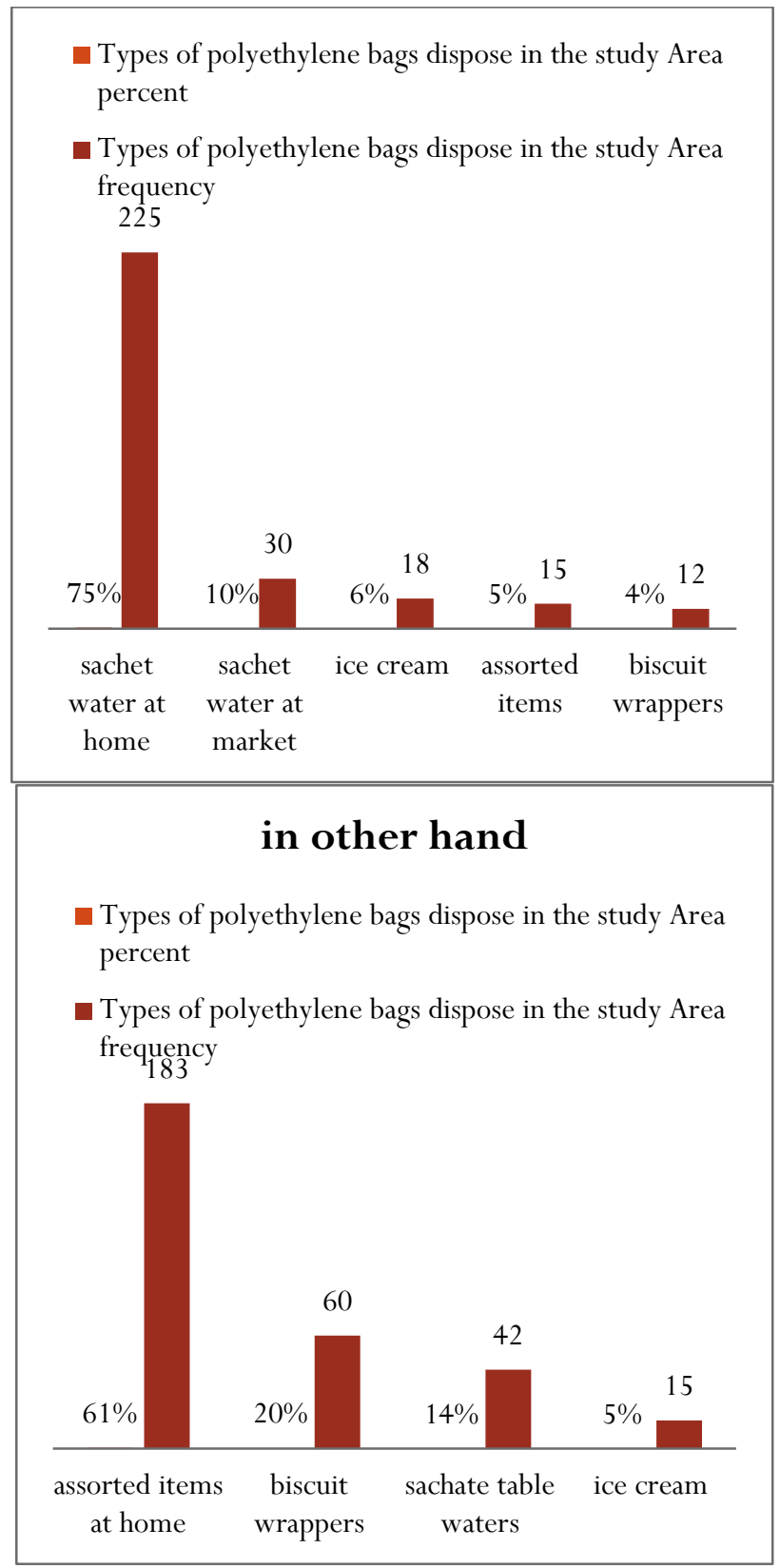

Figure 3. Represents the place with highest disposal of polyethylene bags.

Table 3: shows responses based on environmental impacts of polyethylene bags on the study area Degree of awareness on the highest risk of impacts of disposal of polyethylene bags: Generally, the respondents in the study area had the notion that there are some extents at which pollution on disposal of polyethylene affects environmental resources out of which crop yield was considered. The extent of the effect on crop revealed that $10.7 \%$ of the respondents claimed that the extent on the effect of pollution on crop due to the disposal of polyethylene bags was total damage while about $89.3 \%$ believed that the damage was partial. Moreover, $19.7 \%$ of the respondents claimed that rampant disposal causes partial damage in aquatic lives while $80.3 \%$ affirmed that the pollution does not cause any damage to the aquatic lives. 
Generally, it is believed that pollution based on highest disposal of polyethylene is very dangerous to human health and livelihood. But within the study area, only $15 \%$ of the total respondents agreed that rampant disposal of polyethylene bags causes some disease like cough, malaria, cholera, and when it burn on air agreed to causes cancer, asthma and catarrh while $85 \%$ did not responded. And also 65\% agreed that polyethylene bags are the major causes of pollution, in which $25 \%$ responded that agricultural waste, are the major of causes of environmental pollution not a polyethylene bags while $10 \%$ agreed that both are the causes of environmental pollution.

Table 3. The result of the analysis on the rate of occurrence or causes of pollution by polyethylene bags in the study area

\section{Response Based on Environmental Impacts of Polyethylene in the Study Area}

\section{Responses on Polyethylene Bags are Major the Causes of}

Pollution Based on the Respondents

\begin{tabular}{|c|c|c|c|c|c|}
\hline Responses & percent & Frequency & $\begin{array}{l}\text { disposal } \\
\text { environme } \\
\text { which cro }\end{array}$ & $\begin{array}{l}\text { polyethyl } \\
\text { al resour } \\
\text { ield was c }\end{array}$ & $\begin{array}{l}\text { ne affects } \\
\text { es out of } \\
\text { onsidered }\end{array}$ \\
\hline Response to yes & $65 \%$ & 195 & responses & percent & frequency \\
\hline Response to No & $25 \%$ & 75 & $\begin{array}{l}\text { it has } \\
\text { effect }\end{array}$ & $10.70 \%$ & 32 \\
\hline Response to both & $10 \%$ & 30 & $\begin{array}{l}\text { it does } \\
\text { not has } \\
\text { effect }\end{array}$ & $89.30 \%$ & 268 \\
\hline Total & $100 \%$ & 300 & & $100.00 \%$ & 300 \\
\hline $\begin{array}{l}\text { The respondents claim } \\
\text { partial damage in aqua }\end{array}$ & $\begin{array}{l}\text { at rampan } \\
\text { ves }\end{array}$ & disposal causes & $\begin{array}{l}\text { Response } \\
\text { disposal o } \\
\text { causes son }\end{array}$ & $\begin{array}{l}\text { sed on ra } \\
\text { olyethyles } \\
\text { disease }\end{array}$ & $\begin{array}{l}\text { pant } \\
\text { e bags }\end{array}$ \\
\hline Responses & percent & frequency & responses & percent & frequency \\
\hline Yes it causes damage & $19.70 \%$ & 59 & $\begin{array}{l}\text { yes it has } \\
\text { health } \\
\text { effect }\end{array}$ & $15 \%$ & 45 \\
\hline $\begin{array}{l}\text { No does not cause any } \\
\text { damage }\end{array}$ & $80.30 \%$ & 241 & $\begin{array}{l}\text { did not } \\
\text { respond }\end{array}$ & $85 \%$ & 255 \\
\hline Total & $100.00 \%$ & 300 & total & $100 \%$ & 300 \\
\hline
\end{tabular}



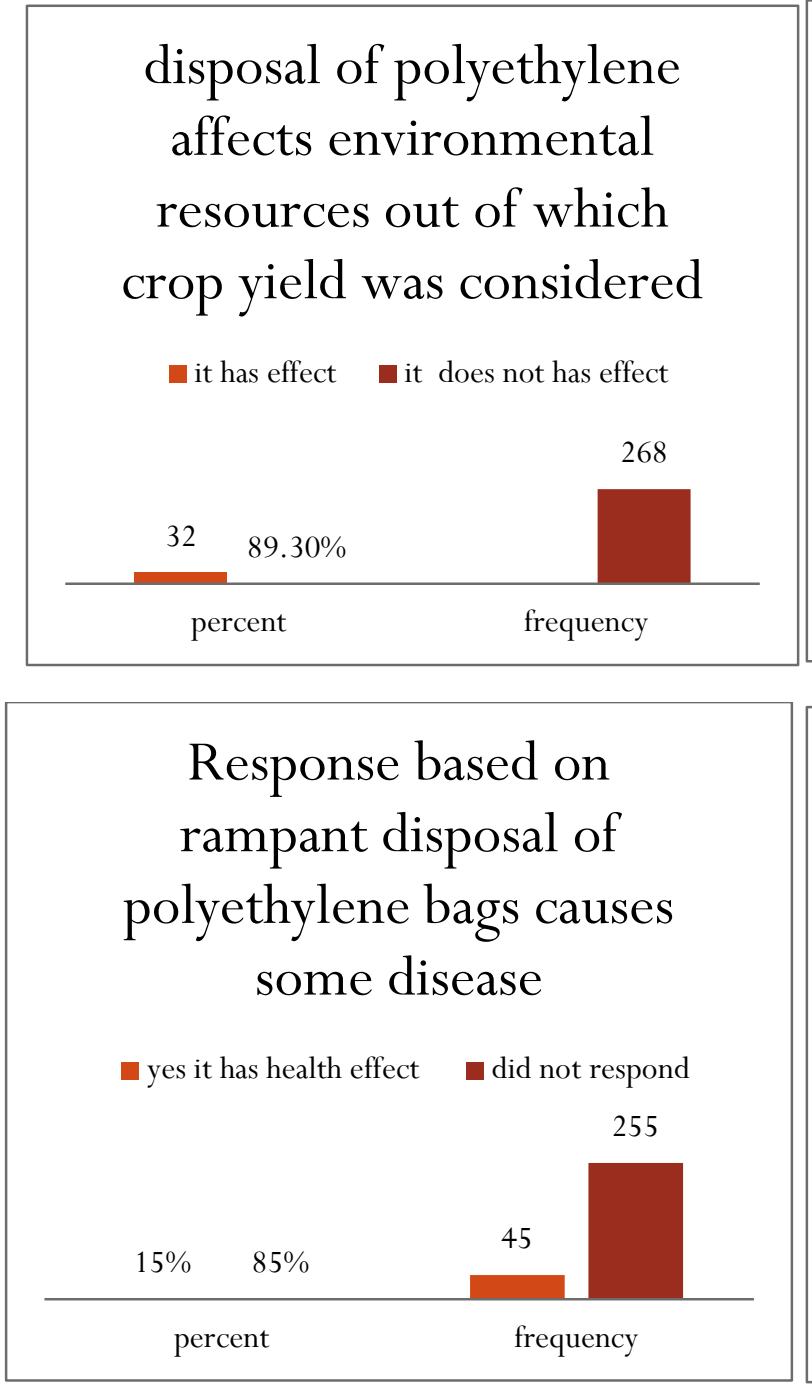

the respondents claimed that rampant disposal causes partial damage in aquatic lives

yes it causes damage

NO does not cause any damage

\begin{tabular}{cc|}
$19.70 \% 80.30 \%$ & $59 \overbrace{}^{241}$ \\
\hline percent & frequency \\
\hline
\end{tabular}

Figure 4. Represent responses based on pollution and health effect of polyethylene bags in the study area

On the question as to why polyethylene bags are disposed indiscriminately by the respondents, the most outstanding reasons given include lack of waste bins in private and public places/vehicles; poor attitude of Nigerians more especially in Gusau city towards waste disposal and environmental sanitation, no adequate punishment for environmental violators/abusers. Personal observation and experience reveal that virtually every Nigerian is guilty of this indiscriminate waste disposal since both the educated and illiterate, rich or poor, old or young throw away any waste anywhere and anytime he is done with the content.

\section{Conclusion}

Polyethylene waste poses various threats to public health and adversely affects flora and fauna as well as the environment especially when it is not appropriately collected and properly disposed. And based on this research, it was found that most of the public do not know the advantages, disadvantages and the health effects of rampant and improper disposal of 
polyethylene bags. It is concluded that aggressive campaign and enlightenment of the masses on the threats posed by polyethylene bags pollution should be carried out to prevent further negative environmental impact. Since polyethylene is not recycled in Nigeria or adequately disposed of, they are ever present on the landscape not-with-standing whether it is rural or urban. The environment is therefore, filthily coloured with all shades of polyethylene resulting in a drastic reduction of environmental aesthetics. This form of eyesore resulting largely from environmental abuse and degradation is worst in Gusau city areas. The polyethylene is also capable of holding rain for days, weeks and months. These small pools of water are usually breeding ground for mosquitoes thereby increasing the incidence of malaria in Zamfara state and Nigeria in general. Presently, the type and magnitude of soil and water pollution in Gusau and Nigeria in general is not fully known. However, there is the fear that if the situation is not checked immediately, chances are that our environments will become seriously unsustainable in the future. To guide against this, it was recommended that,

\section{Recommendations}

1. Appropriate measures should be put in place to properly dispose the non- biodegradable items. In furtherance of these measures, it is recommended that aggressive campaign and enlightenment of the masses on the risks and dangers of rampant disposal of polyethylene bags should be carried out. This can be achieved through public lectures, jingles and adverts as the case may be. Hopefully, this approach will change their current attitude as it pertains to indiscriminate disposal of polyethylene bags.

2. Government should provide public waste bins in strategic positions along the streets, and other public places. These waste bins should be collected and adequately disposed of regularly. More personnel should be employed in the Ministry of Environment. Environmental Health Officers and equipment's should be strengthened to be able to meet the demand of the present environment within the context of waste disposal.

3. Currently, manpower and equipment are grossly inadequate in this ministry. People who are found to be physically abusing the environment should be arrested, charged and punished if found guilty. The hitherto monthly environmental sanitation programme as presently practiced in the State should be reinvigorated.

4. It is equally recommended that the recycling aspect of the polyethylene products should be seriously considered. The government can do this by contracting polyethylene products collection and disposal out rightly. If this is done, and the people are aware that they will be paid for proper used of polyethylene bags, they will definitely be encouraged to preserve the ones used. This will create a means of sustainable employment for the women, children and the generally unemployed.

\section{References}

A. O. Akinro, O. B Ikumawoyi, Olotu Yahaya \& M.M. Ologunagba Environmental Impacts of Polyethylene Generation and Disposal in Akure City, Nigeria Volume 12 Issue 3 Version 1.0 March 2012 Type: Double Blind Peer Reviewed International Research Journal Publisher: Global Journals Inc. (USA)

Addison, R. F, Hansen, P.D and Wrigth, E. C., 1991. Hepatic Mon-Oxygenase Activities in American place from Miramichi Estuary, N.B. Canadian Technical Report of fisheries and Aquatic science No. 1800 Fisheries and Oceans 
Agagu, O. K., 2009. Threats to the Nigerian environment: a call for positive action. Being a paper delivered at the 2009 Chief S.L. Edu Memorial Lecture, Nigerian Conservation Foundation, and Lagos. 42pp Awake, 2002. Garbage will it Bury us? August 22,83(16): 3-11

Anthony A (2003). Plastics and the environment. New Jersey: John Wiley \& Sons, Inc. Hoboken, New Jersey, pp. 379-397.

Bjerkli CL (2005). The cycle of plastic waste: an analysis on the informal plastic recovery system in Addis Ababa, Ethiopia. Master thesis. Norwegian Univ. Sci.Technol., pp.40-49.

Day, L., 1998. Wise up on Waste. Envirokids, Vol. 19 (3): 17

Flores MC (2008) Plastic materials and environmental externalities: Structural causes and corrective policy. Lethbridge Undergraduate Res. J., 3(2).

Geographical (2005). "Waste: An Overview." Geographical, 77(9): 34 -35.

Geradu, J. (1995) spatial planning and the environment, IPC 681, The Netherlands Ministry of Hunsing 20-24pp.

Hasson R, Leiman A, Visser M (2007). The Economics of plastic bag legislation in south Africa. South African J. Econ., 75 (1): 66-83.

Macur BM, Pudlowski ZJ (2009). Plastic bags- a hazard for the environment and a challenge for contemporary engineering educators. World Trans. Engineer. Technol. Educ., 7(2): $122-126$.

Obafemi, a a; Eludoyin, o s; Skinbosola, b m, Public Perception of Environmental Pollution in Warri, Nigeria, J. Appl. Sci. Environ. Manage. Sept., 2012 Vol. 16 (2) 233 - 240

Palmer, J. A., 1998. Environmental Education in the 21st Century. Theory, Practice, Progress and Promise. Rutledge, London. pp. $35-37$

Ramaswamy V, Sharma HR (2011). Plastic bags - threat to environment and cattle health: A retrospective study from Gondar city of Ethiopia. The Official J. Inst. Integromics Appl. Biotech. J., 21: 7-12.

Spokas KA (2007). Plastics: still young, but having a mature impact. Waste Manage., 28(3): 473-474.

Stevens E (2001). Green Plastics: An introduction to the new science of biodegradable plastics. Princeton, NJ: Princeton University Press, pp 15-30.

United Nations Environment Programme (UNEP) (2005a). Plastic bag ban in Kenya proposed as part of a new waste strategy. UNEP press release.

Xing X (2009). Study on the ban on free plastic bags in China. J. Sustain. Dev., 2: 156-158 